\title{
Reconsideration of the proposed luteotropic and luteoprotective actions of ovine placental lactogen in sheep: in vivo and in vitro studies
}

\author{
K H Al-Gubory, S Camous, G Germain, P Bolifraud, A Nicole ${ }^{1}$ \\ and I Ceballos-Picot ${ }^{1}$ \\ Unité Biologie du Développement et de la Reproduction, Département de Physiologie Animale, Institut National de la Recherche Agronomique (INRA), \\ 78352 Jouy-en-Josas cedex, France \\ ${ }^{1}$ Laboratoire de Biochimie Médicale, Centre Hospitalier Universitaire de Necker, Institut National de la Santé et de la Recherche Médicale (INSERM), \\ 75743 Paris cedex 15, France \\ (Requests for offprints should be addressed to K H Al-Gubory; Email: kais.algubory@jouy.inra.fr)
}

\begin{abstract}
Ovine placental lactogen (oPL) is produced by the conceptus trophectoderm and is secreted into both the maternal and fetal circulations. The present study was designed to examine in vivo the luteotropic effect of recombinant oPL (roPL), as determined by monitoring progesterone concentration and cycle length (experiment 1), and the antioxidative and antiapoptotic effects of roPL, as determined respectively by monitoring antioxidant enzymatic activity and apoptosis in the corpus luteum (CL) of cyclic ewes (experiment 2). We also studied whether roPL is capable of stimulating progesterone secretion in vitro by cultured luteal tissue of functionally active CL obtained from day-10 cyclic ewes (experiment 3 ) and day-60 pregnant ewes (experiment 4). Circulating concentrations of progesterone and cycle length were not affected by treatment of ewes with $80 \mu \mathrm{g} / \mathrm{kg}$ body weight per day of roPL ( $n=4$ ewes) for 10 days beginning on day 11 post-estrus, as compared with saline-treated ewes $(n=4$ ewes). Luteolysis occurred between days 15 and 16 postestrus in the four saline-treated ewes and in 3/4 roPLtreated ewes. The activities of the key antioxidant enzymes
\end{abstract}

copper-zinc superoxide dismutase (Cu,Zn-SOD), manganese SOD (Mn-SOD), glutathione peroxidase (GPX), glutathione reductase (GSR) and glutathione S-transferase (GST) were unaffected by treatment of ewes with $80 \mu \mathrm{g} / \mathrm{kg}$ per day of roPL ( $n=4$ ewes) for 3 days, between days 11 and 14 post-estrus, as compared with salinetreated ewes ( $n=4$ ewes). In situ TUNEL method revealed that the number of apoptotic cells was not different between the two groups of ewes. There was no significant change in progesterone secretion by explants from day-10 estrous cycle ( $n=3$ ewes) or day-60 pregnancy ( $n=3$ ewes) CL cultured with different concentrations $(10,100$ and $1000 \mathrm{ng} / \mathrm{ml}$ ) of roPL, whereas treatment with oLH at the concentration of 100 or $1000 \mathrm{ng} / \mathrm{ml}$ caused a significant increase in progesterone secretion by explants from day-10 estrous cycle CL $(P<0 \cdot 05)$ and by explants from day-60 pregnancy CL $(P<0 \cdot 01)$. In conclusion, our results demonstrate that oPL has no luteotropic and/or luteoprotective actions in sheep, either in vivo or in vitro.

Journal of Endocrinology (2006) 188, 559-568

\section{Introduction}

Despite recent advances in reproductive technology, farm producers are still faced with the persistent problem of low fertility. Inadequate corpus luteum (CL) production of progesterone is likely to be a presumptive cause of early embryonic loss and pregnancy failure in sheep and cattle (Ayalon 1978, Ashworth et al. 1989, Shelton et al. 1990, Thatcher et al. 1994). Thus, researchers have specifically proposed progesterone supplementation after breeding to compensate for poor luteal steroidogenic activity in beef cattle (Garrett et al. 1988), dairy cows (Robinson et al. 1989), ewe lambs (Davies \& Beck 1992) and mature ewes
(Kleemann et al. 1994, Nephew et al. 1994). An alternative strategy to increase progesterone concentrations is the use of luteotropic hormones. Pituitary luteinizing hormone (LH) is well known as the main luteotropin in domestic ruminants (Denamur 1968, Kaltenbach et al. 1968, Denamur et al. 1973, Niswender 2002). Human chorionic gonadotropin (hCG), the main luteotropic signal produced by the primate trophoblast, has activity similar to that of LH. Thus, researchers have used hCG in their attempts to increase reproductive performance in ruminants. Treatment of cattle (Rajamahendran \& Sianangama 1992, Schmitt et al. 1996, Santos et al. 2001) and sheep (Beck et al. 1999, Khan et al. 2003, 
Akif Cam \& Kuran 2004) with hCG induces formation of accessory CL, enhances plasma progesterone concentration and improves reproductive performance. In spite of the encouraging results obtained, the use of hCG in ruminants may create problems in animal fertility. For example, repeated use of equine (e)CG has been shown to decrease fertility in goats (Roy et al. 1999a) and ewes (Roy et al. 1999b). The production of antibodies seems to explain the adverse effect of eCG on fertility in domestic ruminants (Chimineau et al. 1999, Roy et al. 1999a,b). Therefore, to minimize unwanted immunologic responses, alternative strategies using luteotropins to improve pregnancy rates require investigations to be conducted in homologous species.

The placenta of ruminant species produces regulatory factors, including placental lactogens (PLs), also known as chorionic somatomammotropin (oCS). In sheep, the presumed luteotropic action of ovine PL (oPL) was first suggested by Kelly et al. (1974), who showed that a rise in oPL during late pregnancy paralleled the increase in progesterone secretion observed at that time. Shortly after the discovery of ruminant PL, it was purified from term placentae of ewes (Martal \& Djiane 1975) and cows (Bolander \& Fellows 1976). oPL is synthesized by the trophoblast as early as day 16 of pregnancy (Carnegie $e t$ al. 1977, Martal \& Djiane 1977) and is found to be present in the peripheral circulation in increasing amounts as pregnancy progresses (Chan et al. 1978a). Specific binding sites for oPL have been detected in various tissues, including the CL, obtained from nonpregnant and pregnant ewes (Chan et al. 1978b). Evidence indicates that the ovine prolactin (oPRL) receptor transduces signals by oPL, because this hormone homodimerizes the oPRL receptor and activates signaling pathways (Herman et al. 2000). In addition, one property of ruminant PLs is their ability to bind both PRL and growth hormone $(\mathrm{GH})$ receptors (for review, see Gertler \& Djiane 2002). In spite of these investigations, little attention has been given so far to studying the luteotropic role of oPL in sheep. The lack of definitive evidence of this role has been due to the difficulty in obtaining sufficient quantities of the native hormone required for homologous in vivo experiments. The oPL has been cloned, and the recombinant form of this hormone has been produced (Sakal et al. 1997). It is expected that this will greatly facilitate investigations on the function of PL in sheep. For example, delineating the luteotropic action of oPL may provide new opportunities to minimize the incidence of early embryonic mortality in current production systems.

The present study was designed to examine in vivo:

1. the luteotropic effect of recombinant oPL (roPL), as determined by monitoring progesterone secretion from the $\mathrm{CL}$ of cyclic ewes treated with roPL (experiment 1).
2. the antiapoptotic and antioxidative effects of roPL, as determined respectively by monitoring apoptosis and antioxidant enzymatic activity in the CL of cyclic ewes treated with roPL (experiment 2).

We also studied whether roPL can stimulate progesterone secretion in vitro by cultured luteal tissue of functionally active CL obtained from day-10 cyclic ewes (experiment 3) and day-60 pregnant ewes (experiment 4).

\section{Materials and Methods}

\section{Animals}

All procedures relating to care and use of animals were approved by the French Ministry of Agriculture according to French regulations for animal experimentation (authorization no. 78-34). The study involved cyclic and pregnant ewes of the Préalpes-du-Sud breed. The ewes were treated for 14 days with intravaginal sponges containing $40 \mathrm{mg}$ fluorogestone acetate (Intervet, Angers, France) to synchronize estrus, as previously described (Menegatos et al. 2003). After sponge removal, each ewe received an intramuscular injection of 400 IU eCG (Intervet). Ewes assigned to the pregnant group were mated twice at the time of the synchronized estrus with fertile rams, at an interval of $12 \mathrm{~h}$. All ewes used were housed under conditions of natural day length and temperature.

\section{Experiments 1 and 2: in vivo effect of roPL on $C L$} functional life span and structure

Experiment 1 was designed to examine the luteotropic effect of roPL as determined by monitoring progesterone secretion from the CL of cyclic ewes. Experiment 2 was designed to examine the antiapoptotic and antioxidative effects of roPL as determined by monitoring apoptosis and antioxidant enzymatic activity in the CL of cyclic ewes respectively. Sixteen ewes were randomly assigned to one of two treatments: $80 \mu \mathrm{g}$ roPL $/ \mathrm{kg}$ live weight $/$ day $(n=8$ ewes) or saline ( $n=8$ ewes). In experiment 1 , the ewes were treated with an intramuscular injection of $1 \mathrm{ml}$ saline $(n=4$ ewes) or roPL ( $n=4$ ewes) twice daily (at 0800 and $2000 \mathrm{~h}$ ) for 10 days. In experiment 2 , the ewes were treated with saline ( $n=4$ ewes) or roPL $(n=4$ ewes) for 3 days. In both experiments, treatments were started on day 11 of the estrous cycle. The roPL used in the present study has mammogenic and lactogenic effects in ewes (Kann et al. 1999), and the dose used was selected because it had been shown to mimic the peripheral concentration of this hormone during midpregnancy (Kann et al. 1999). Blood samples $(3 \mathrm{ml})$ were taken daily from the jugular vein into evacuated heparinized tubes, beginning on day 11 of the estrous cycle. After centrifugation $\left(3000 \mathrm{~g}, 4{ }^{\circ} \mathrm{C}\right)$ 
for $30 \mathrm{~min}$, plasma was stored at $-20{ }^{\circ} \mathrm{C}$ until assayed. In experiment 2 , the ewes were killed on day 14 post-estrus at a local abattoir in accordance with protocols approved by the local institutional animal use committee. After slaughter of ewes, the reproductive tracts were collected immediately and transported to the laboratory, and the CL were dissected from the surrounding ovarian tissue. The CL was snap-frozen in liquid nitrogen and then stored at $-80{ }^{\circ} \mathrm{C}$ until processed for the activities of copper-zinc superoxide dismutase $(\mathrm{Cu}, \mathrm{Zn}-\mathrm{SOD})$, manganese $\mathrm{SOD}$ (Mn-SOD), glutathione peroxidase (GPX), glutathione reductase (GSR) and glutathione S-transferase (GST). For the determination of apoptosis, a piece of each CL was fixed overnight in freshly prepared 4\% paraformaldehyde in PBS ( $\mathrm{pH} \mathrm{7.4),} \mathrm{washed} \mathrm{in} \mathrm{PBS,} \mathrm{dehydrated} \mathrm{through} \mathrm{a}$ series of increasing concentrations of ethanol (70-100\%), cleared in xylene and embedded in paraffin wax.

\section{Experiments 3 and 4: in vitro effect of roPL on luteal progesterone secretion}

These experiments were designed to examine the effect of roPL on progesterone secretion by cultured luteal tissue obtained from day-10 cyclic ewes $(n=3$ ewes, experiment $3)$ and day-60 pregnant ewes ( $n=3$ ewes, experiment 4$)$. Ovaries were collected from each ewe within 5 min after slaughter at a local abattoir and were transported immediately to the laboratory. From each ewe, one CL was dissected from the ovarian stroma, freed from its surrounding connective-tissue envelope, and cut into $1 \mathrm{~mm}^{3}$ explants, each weighing $15-30 \mathrm{mg}$. They were then pooled and distributed randomly among treatments. Explants were placed (1 explant $/ \mathrm{ml}$ per well in a 24-well culture plate) in DMEM:F12 serum-free medium (SigmaAldrich) containing $25 \mathrm{mM}$ Hepes, $100 \mathrm{IU} / \mathrm{ml}$ penicillin, $100 \mu \mathrm{g} / \mathrm{ml}$ streptomycin and $0 \cdot 1 \%$ BSA. In experiment 3 , luteal tissue explants from each cyclic ewe were cultured alone (basal) and with different concentrations (10, 100 and $1000 \mathrm{ng} / \mathrm{ml}$ ) of roPL or oLH. In experiment 4, luteal tissue explants from each pregnant ewe were cultured alone (basal) and with different concentrations (10, 100 and $1000 \mathrm{ng} / \mathrm{ml}$ ) of roPL or oLH. In both experiments, incubations of luteal tissue explants from each ewe were performed in triplicate at $37{ }^{\circ} \mathrm{C}$ for $24 \mathrm{~h}$ under a humidified atmosphere of $95 \%$ air and $5 \% \mathrm{CO}_{2}$. At the end of the incubation period, the weight of each explant was recorded, and the media were stored at $-20{ }^{\circ} \mathrm{C}$ until assayed. Progesterone secretion over the $24-\mathrm{h}$ incubation period by luteal explants was normalized with tissue weight, and secretion was expressed as $\mathrm{ng} / \mathrm{mg}$ of tissue.

\section{Progesterone assay}

Plasma samples and incubation media were analyzed for progesterone concentration in duplicate by direct RIA, as previously described in Schanbacher (1979) with some modifications. Charcoal-dextran solution was used instead of polyethylene glycol for the separation of bound and free radioactivity. Tritiated progesterone $\left(1,2,6,7-{ }^{3} \mathrm{H}-\right.$ progesterone, sp act $88 \mathrm{Ci} / \mathrm{mmol}$ ) was obtained from Amersham, and a specific antiprogesterone antibody was obtained from the Institut Pasteur (Paris, France). Hormone preparations, progesterone tracer and other reagents were diluted in $0 \cdot 1 \mathrm{M}$ PBS $(\mathrm{pH} 7 \cdot 25)$. Approximately 3000 c.p.m. tritiated progesterone in $100 \mu \mathrm{l}$ buffer, $100 \mu \mathrm{l}$ progesterone antiserum (1/20 000 dilution), $20 \mu \mathrm{l}$ progesterone standard, plasma samples or incubation media, and $80 \mu \mathrm{l}$ buffer were dispensed into the assay tubes. After an initial 2-h incubation at laboratory temperature $\left(21{ }^{\circ} \mathrm{C}\right)$ followed by $24-\mathrm{h}$ incubation at $4{ }^{\circ} \mathrm{C}, 2 \cdot 2 \mathrm{ml}$ cold charcoal-dextran solution containing $0 \cdot 1 \%$ gelatin was added, and the tubes were centrifuged at $3000 \mathrm{~g}$ for $45 \mathrm{~min}$. The supernatant was decanted into vials, and $3 \mathrm{ml}$ scintillation fluid (Scintillator Plus; PerkinElmer Life \& Analytical Sciences, Boston, MA, USA) were added to each vial. The radioactivity was then counted in a Packard Tri-Carb Liquid Scintillation analyzer (model 2100 TR; Groningen, The Netherlands). To minimize assay variability, all plasma samples or incubation media were analyzed in a single RIA. The limit of assay sensitivity was $0 \cdot 1 \mathrm{ng} / \mathrm{ml}$, and the intra-assay coefficient of variation was less than $10 \%$.

\section{Ovine placental lactogen assay}

Plasma concentrations of roPL were measured in duplicate by a previously described double-antibody RIA (Chan et al. 1978a) with slight modifications. The roPL was radioiodinated by the chloramine $\mathrm{T}$ method (Greenwood et al. 1963) and then purified on disposable PD-10 columns packed with Sephadex G25. Hormone preparations, roPL tracer and other reagents were diluted in $0 \cdot 1 \mathrm{M}$ barbital sodium buffer ( $\mathrm{pH} 8 \cdot 6$ ), containing $0 \cdot 25 \%$ BSA and 0.004 M EDTA. Approximately 22000 c.p.m. ${ }^{125} \mathrm{I}$-roPL in $100 \mu \mathrm{l}$ buffer, $100 \mu \mathrm{l}$ oPL antiserum $(1 / 7700$ dilution), $20 \mu \mathrm{l}$ roPL standard or plasma samples, and $330 \mu \mathrm{l}$ buffer were dispensed into the assay tubes. After a 96-h incubation at $10^{\circ} \mathrm{C}, 100 \mu \mathrm{l}$ sheep anti-rabbit $\gamma$-globulin serum (1/10 dilution) were added to each assay tube. After 10-min incubation at laboratory temperature $\left(21^{\circ} \mathrm{C}\right), 2 \mathrm{ml}$ polyethylene glycol 6000 (4.4\%) were added. The resulting precipitates were centrifuged at $3000 \mathrm{~g}$ for $45 \mathrm{~min}$, and the supernatant was discarded. The radioactivity in the precipitates was then counted in the LKB automatic $\gamma$-counter (model 1272 Clinigamma). The limit of assay sensitivity was $2.5 \mathrm{ng} / \mathrm{ml}$, and the intra-assay coefficient of variation was less than $10 \%$.

\section{Antioxidant enzyme assays}

Frozen, unthawed luteal tissues corresponding to each CL were homogenized separately in $50 \mathrm{mM}$ phosphate buffer 
(pH 7.4) before centrifugation at $15000 \mathrm{~g}$ for $30 \mathrm{~min}$ at $4{ }^{\circ} \mathrm{C}$. The resulting supernatant was used for determination of protein concentration and measurement of activities of $\mathrm{Cu}, \mathrm{Zn}-\mathrm{SOD}, \mathrm{Mn}-\mathrm{SOD}, \mathrm{GPX}, \mathrm{GSR}$ and GST. Protein concentrations were determined by Lowry's method (Lowry et al. 1951). Enzyme activities in the supernatant of each CL were determined in duplicate on a Cobas-Bio centrifugal analyzer (Hoffman-LaRoche, Basel, Switzerland), according to a modification of the method (Wheeler et al. 1990), as previously described and validated (Ceballos-Picot et al. 1992). Activity of each enzyme was determined as previously described in detail (Al-Gubory et al. 2005).

In situ detection of apoptosis by terminal deoxynucleotidyl transferase (TdT)-mediated dUTP nick-end labeling

(TUNEL) method

Luteal apoptotic cells were identified with the In Situ Cell Death Detection Fluorescein Kit (Roche). This assay detects nuclear DNA fragmentation in apoptotic cells by the TUNEL method according to Gavrieli et al. (1992). Briefly, tissue sections (6 $\mu \mathrm{m}$ thick) were prepared, mounted on silane-coated slides (3-amino-propyltriethoxysilane-coated slides; Sigma-Aldrich) and rehydrated through a series of decreasing concentrations of ethanol (100-70\%) to water. They were then treated with $100 \mu \mathrm{g} / \mathrm{ml}$ Proteinase $\mathrm{K}$ (Sigma-Aldrich) in $10 \mathrm{mM}$ Tris (pH 8.0), for $30 \mathrm{~min}$ at $37^{\circ} \mathrm{C}$ and washed with PBS (pH $7 \cdot 4$ ). The slides were submerged in $0 \cdot 1 \mathrm{M}$ sodium citrate for $30 \mathrm{~min}$ at $70{ }^{\circ} \mathrm{C}$ and then washed with PBS. Sections were incubated for $60 \mathrm{~min}$ at $37^{\circ} \mathrm{C}$ with the TUNEL mixture, washed with PBS and counterstained with an aqueous solution of propidium iodide (DNA-PREP stain; Beckman Coulter, Miami, FL, USA) for $60 \mathrm{~min}$ at room temperature, to detect red-staining nonfragmented cell nuclei. Tissue sections were analyzed under a fluorescent microscope. Negative control sections were processed identically except that the labeling enzyme (terminal deoxynucleotidyl transferase) was omitted. Four different optical fields (magnification 250) were selected in a random manner for each CL tissue section and used to calculate the percentage of apoptotic nuclei.

\section{Statistical analysis}

In vitro experiments were repeated three times, using a different ewe for each experiment. Since concentrations of progesterone secretion over the 24-h incubation by luteal explants varied widely between ewes, progesterone values were expressed as a percentage of the basal secretion rate. The data are given as the mean \pm S.E.M. of triplicate treatments for each of the three experiments. Differences in concentration of progesterone in culture media between the control and treated explants were assessed by one-way ANOVA followed by Dunnett's multiple-range

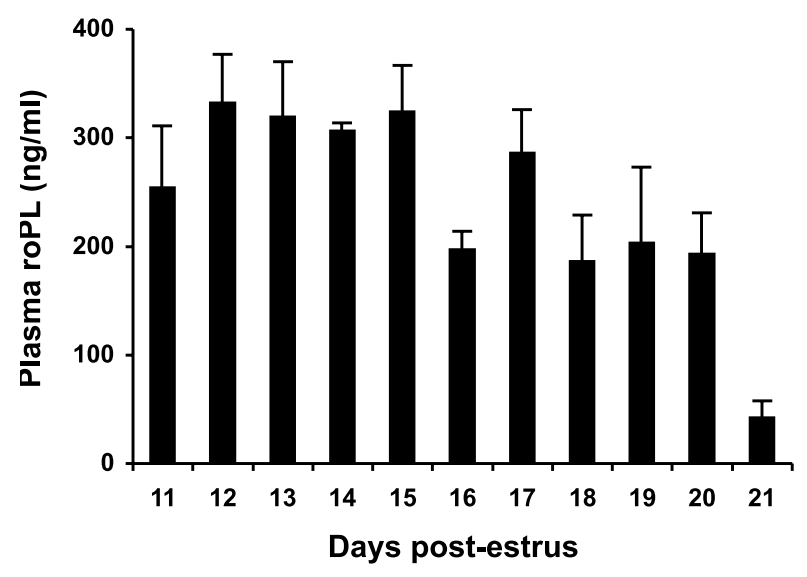

Figure 1 Mean ( \pm S.E.M.) recombinant oPL (roPL) concentrations in jugular blood samples collected daily from four roPL-treated ewes. Ewes were treated with roPL at a dose of $80 \mu \mathrm{g} / \mathrm{kg}$ live weight per day twice daily (at 0800 and $2000 \mathrm{~h}$ ), starting on day 11 of the estrous cycle. Results are from blood samples taken at $0900 \mathrm{~h}$.

test (GraphPad Prism, San Diego, CA, USA). A level of $P<0 \cdot 05$ was accepted as statistically significant.

\section{Results}

\section{Experiment 1}

During roPL treatment $(80 \mu \mathrm{g}$ roPL/kg live weight per day), plasma concentrations of oPL were maintained between 200 and $400 \mathrm{ng} / \mathrm{ml}$, and dropped to $42 \mathrm{ng} / \mathrm{ml}$ at $24 \mathrm{~h}$ after treatment was stopped (Fig. 1). Progesterone concentrations in jugular blood samples collected from the four ewes treated with roPL and the four saline-treated ewes are shown in Fig. 2. In all the saline-treated ewes and in 3/4 roPL-treated ewes, progesterone levels remained high ( $>2 \mathrm{ng} \mathrm{ml}$ ) until day 14 of the estrous cycle, when an abrupt decline occurred, dropping to low $(<1 \mathrm{ng} \mathrm{ml})$ or undetectable levels on days 15-16. This indicates complete functional regression of the CL. Only one of the four roPL-treated ewes showed a prolonged cycle, with complete luteolysis occurring on day 18. The three other roPL-treated ewes showed normal cycles with a duration of 16 days. Spontaneous new ovulations occurred in all the ewes, except for one saline-treated ewe, as evidenced by the rise in progesterone concentrations $(>0.5 \mathrm{ng} / \mathrm{ml})$ 3-6 days after luteolysis. The mean duration ( \pm S.E.M.) from complete luteolysis to return of functional activity of the newly formed CL, as identified by the first elevation of plasma progesterone concentration $(\geq 0.5 \mathrm{ng} / \mathrm{ml})$, was shorter $(P<0 \cdot 05$, unpaired $t$-test $)$ in roPL-treated ewes $(3 \cdot 8 \pm 0 \cdot 3$ days $)$ than in saline-treated ewes $(5 \cdot 8 \pm 0 \cdot 6$ days $)$.

\section{Experiment 2}

There were no significant differences between roPLtreated and saline-treated ewes in the mean ( \pm S.E.M.) 

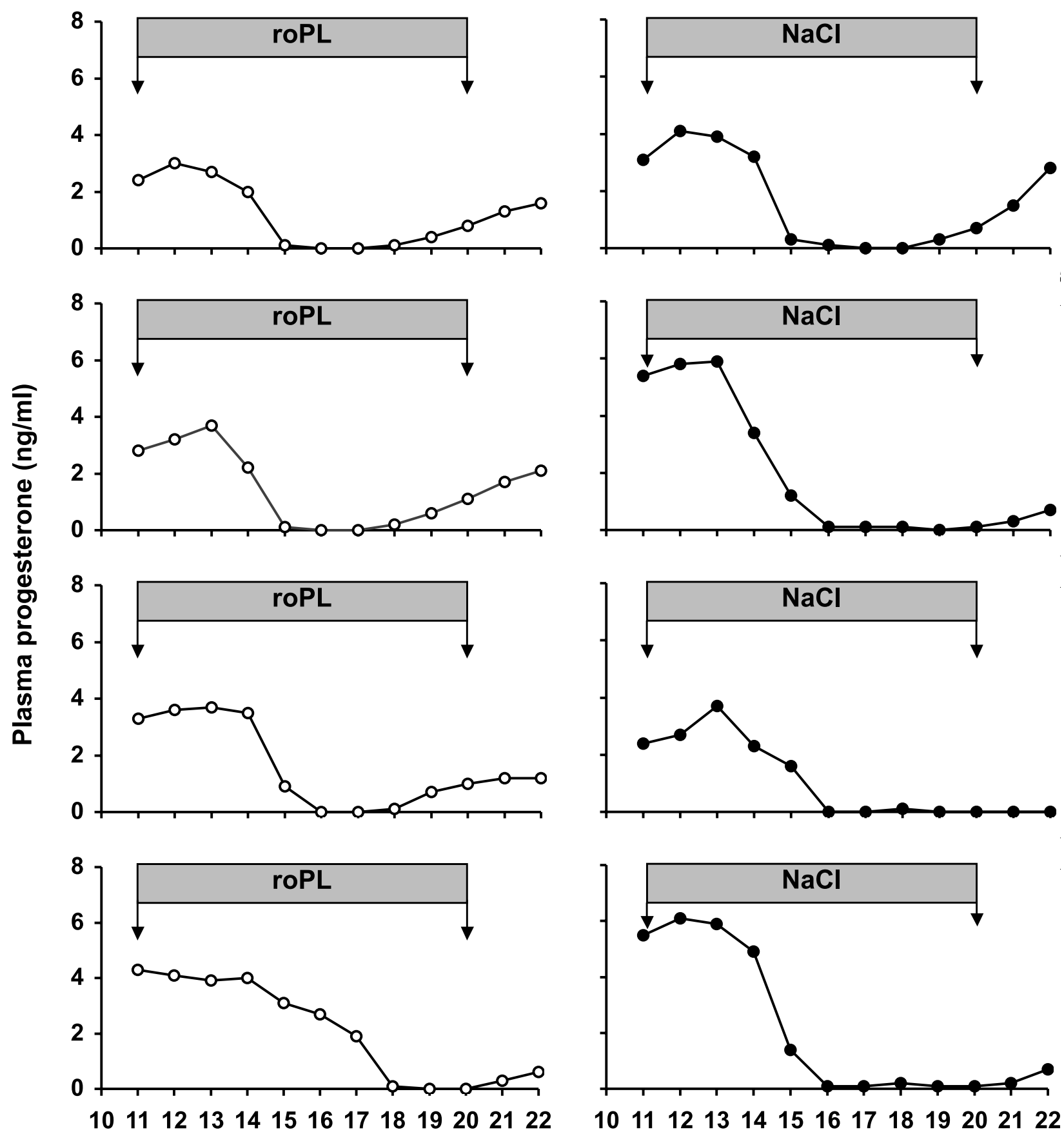

\section{Days post-estrus}

Figure 2 Progesterone concentrations in jugular blood samples collected daily from four ewes treated with recombinant oPL (roPL) and four saline-treated ewes. Ewes were treated with roPL or saline $(\mathrm{NaCl})$ at a dose of $80 \mu \mathrm{g} / \mathrm{kg}$ live weight per day twice daily (at 0800 and $2000 \mathrm{~h}$ ), starting on day 11 of the estrous cycle. Results are from blood samples taken at $0900 \mathrm{~h}$.

activities (U/mg protein) of $\mathrm{Cu}, \mathrm{Zn}-\mathrm{SOD}(71 \cdot 8 \pm 12 \cdot 0$ vs $65 \cdot 3 \pm 12 \cdot 9)$, Mn-SOD $(93 \cdot 0 \pm 8 \cdot 0$ vs $99 \cdot 5 \pm 32 \cdot 3)$, GPX $\quad(45 \cdot 1 \pm 6 \cdot 1$ vs $33 \cdot 0 \pm 2 \cdot 9), \quad$ GSR $\quad(25 \cdot 4 \pm 4 \cdot 7$ vs $24 \cdot 5 \pm 2 \cdot 0)$ and $\operatorname{GST}(287 \cdot 8 \pm 19 \cdot 7$ vs $372 \cdot 7 \pm 81 \cdot 6)$. In situ identification of DNA fragmentation in luteal cells of CL collected at day 14 of the estrous cycle from 

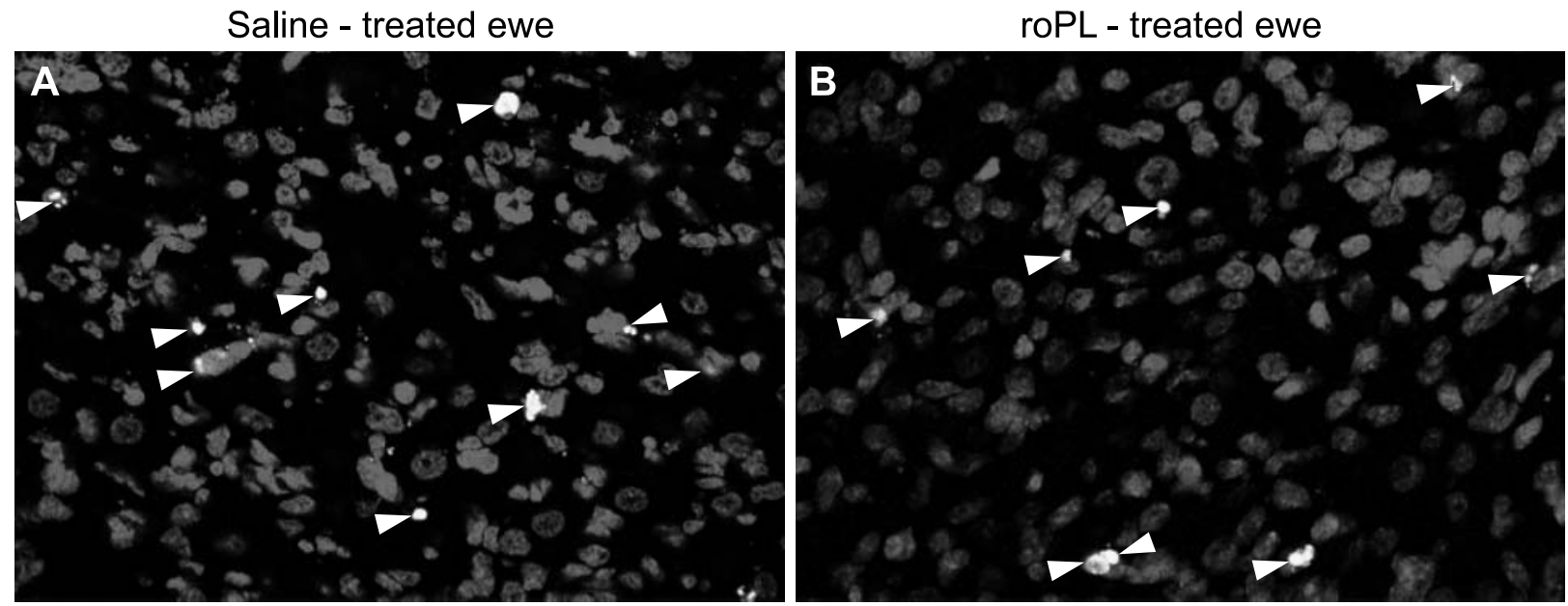

Figure 3 In situ identification of apoptotic cells by fluorescence labeling of nicked DNA in CL on day 14 of the estrous cycle in a representative ewe treated with saline $(\mathrm{NaCl}$; $\mathrm{A}$ ) or recombinant oPL (roPL; B). Ewes were treated with saline or roPL at a dose of $80 \mu \mathrm{g} / \mathrm{kg}$ live weight per day twice daily (at 0800 and 2000 h), between days 11 and 14 post-estrus. Histologic sections $(6 \mu \mathrm{m})$ were subjected to the terminal deoxynucleotidyl transferase-mediated dUTP nick-end labeling (TUNEL) method. Apoptotic nuclei are indicated by arrowheads. Original magnification $\times 250$.

representative oPL-treated and saline-treated ewes is shown in Fig 3. The mean percentage ( \pm S.E.M.) of apoptotic nuclei of luteal cells in roPL-treated ewes $(2 \cdot 0 \pm 0 \cdot 9)$ was not different from that in saline-treated ewes $(3 \cdot 3 \pm 2 \cdot 9)$.

\section{Experiment 3}

Progesterone secretion by luteal explants obtained from CL of day 10 of the estrous cycle was not stimulated by any dose of roPL added to the culture media (Fig. 4). Unlike roPL, addition of oLH to culture media caused a significant increase in progesterone secretion by luteal explants (Fig. 4). The mean progesterone concentration was significantly increased $(P<0 \cdot 05)$ by the addition of 100 and $1000 \mathrm{ng} \mathrm{oLH} / \mathrm{ml}$ as compared with controls.

\section{Experiment 4}

Progesterone secretion by luteal explants obtained from CL of day 60 of pregnancy was not stimulated by any dose

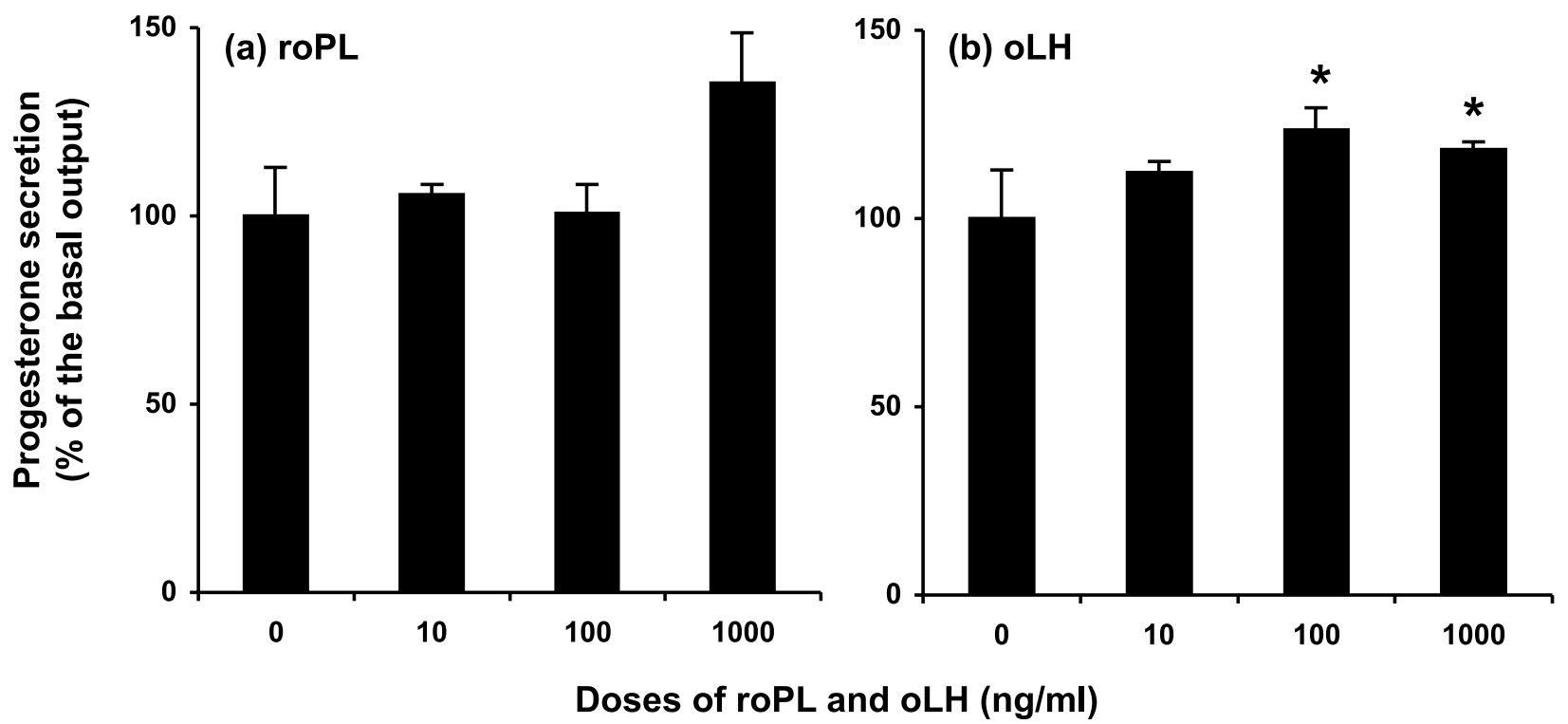

Figure 4 Progesterone secretion by explants of sheep $\mathrm{CL}$ from day 10 of the estrous cycle incubated for $24 \mathrm{~h}$ with different concentrations $(10,100$ and $1000 \mathrm{ng} / \mathrm{ml})$ of (a) recombinant oPL or (b) oLH. Values are mean \pm S.E.M. of triplicate treatments for each of three separate experiments. ${ }^{*} P<0 \cdot 05$ versus controls. 


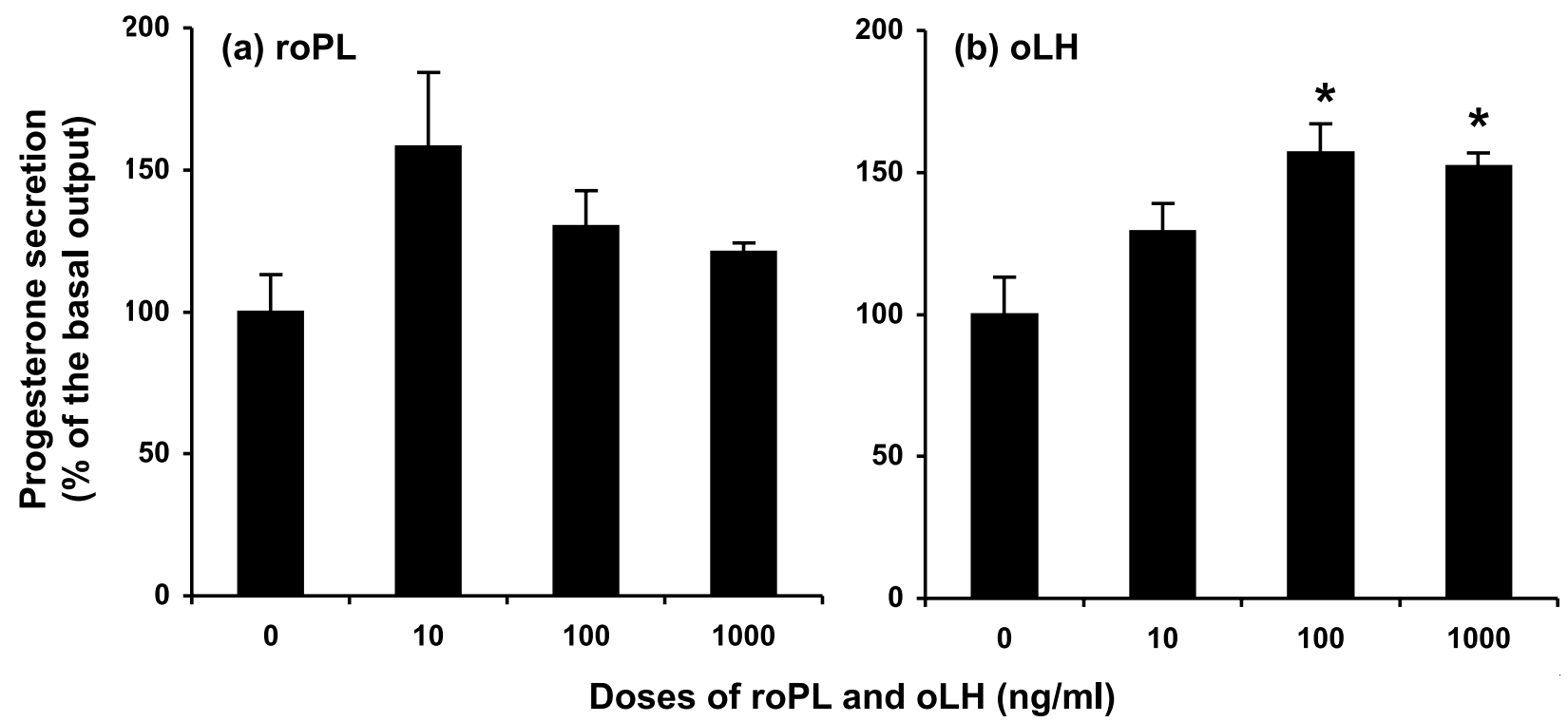

Figure 5 Progesterone secretion by explants of sheep $\mathrm{CL}$ from day 60 of pregnancy incubated for $24 \mathrm{~h}$ with different concentrations $(10,100$ and $1000 \mathrm{ng} / \mathrm{ml}$ ) of (a) recombinant oPL or (b) oLH. Values are mean \pm S.E.M. of triplicate treatments for each of three separate experiments. ${ }^{*} P<0 \cdot 01$ versus controls.

of roPL added to the culture media (Fig. 5). Addition of oLH to culture media caused a significant increase in progesterone secretion by luteal explants (Fig. 5). The mean progesterone concentration was significantly increased $(P<0.01)$ by the addition of 100 and $1000 \mathrm{ng}$ $\mathrm{oLH} / \mathrm{ml}$ as compared with controls.

\section{Discussion}

In rodents, it is well established that luteotropic support of the CL during the second half of pregnancy depends on placental hormones. These hormones, particularly PLs in combination with estradiol, stimulate steroidogenesis by the rat CL (Glaser et al. 1984, Khan et al. 1987; for reviews, see Gibori et al. 1988, Gibori 1993). There is also evidence obtained by in vivo and in vitro studies that PLs play an important role in the regulation of CL function in the mouse (Galosy \& Talamantes 1995). In sheep, the role of $\mathrm{OPL}$ in the regulation of $\mathrm{CL}$ function has been controversial until now. The presumed luteotropic action of oPL was first suggested by Kelly et al. (1974), who showed that a rise in oPL during late pregnancy in ewes paralleled the increase in progesterone secretion observed at that time. However, antibody neutralization of maternal oPL on day 131 of pregnancy in ewes did not affect plasma concentrations of progesterone (Waters et al. 1985).

Prostaglandin F-2 $\alpha\left(\mathrm{PGF}_{2 \alpha}\right)$ of uterine origin is known to be responsible for the periodic regression of the sheep CL (McCracken et al. 1972). At the time of initial functional luteolysis, the first significant rise in the secretion of $\mathrm{PGF}_{2 \alpha}$ occurred on days 12-13 of the sheep estrous cycle (Baird et al. 1976). Administration of $\mathrm{PGF}_{2 \alpha}$ before the onset of luteolysis (on day 10 of the estrous cycle) has been shown to decrease progesterone secretion and induce luteal cell degeneration (Stacy et al. 1976). One of the proposed roles of oPL is its ability to protect the $\mathrm{CL}$ against the luteolytic action of $\mathrm{PGF}_{2 \alpha}$. However, constant infusion of purified oPL on day 12 of the estrous cycle directly into the arterial supply of the ovary for only $9 \mathrm{~h}$ at a rate of $0 \cdot 6,6$ and $60 \mu \mathrm{g} / \mathrm{h}$ or for $32 \mathrm{~h}$ at a rate of $30 \mu \mathrm{g} / \mathrm{h}$ did not prevent a fall in the secretion rate of progesterone when a known luteolytic dose of $\mathrm{PGF}_{2 \alpha}$ was given as a continuous infusion in ewes (Schramm et al. 1984). Possibly the dose of oPL injected and/or the duration of infusion was not enough to counteract the luteolytic action of $\mathrm{PGF}_{2 \alpha}$. One can also speculate that after the initial rise in endogenous secretion of $\mathrm{PGF}_{2 \alpha}$ on day 12 of the estrous cycle (Baird et al. 1976), the CL can no longer be rescued from luteolysis even with oPL treatment. Therefore, in the present study (experiment 1), the luteotropic action of oPL was examined in vivo before the onset of luteolysis. We showed that treatment of ewes for 10 days with roPL at a dose of $80 \mu \mathrm{g} / \mathrm{kg}$ live weight per day, which began before the initiation of luteolysis (day 11 of the estrous cycle), mimicked circulating concentrations of this hormone measured at days 90-100 of pregnancy (Chan et al. 1978a). However, this treatment did not alter luteal progesterone secretion and the functional life span of the CL. Of the four ewes treated with roPL, one ewe displayed an estrous cycle of 18 days in length. Since the duration of the estrous cycle in ewes varies from 16 to 18 days, it is unlikely that the delay in luteolysis in one roPL-treated ewe can be attributed to the 
roPL treatment. After luteolysis, it is surprising to find that ovulation occurred earlier in roPL-treated ewes than in saline-treated ewes (present study). Although the significance of this finding is at present unknown, one might suggest that the short delay between luteolysis and subsequent ovulation in roPL-treated ewes may be related to developmental changes of follicles that ovulate after oPL treatment. Whether oPL has biologic action in the ovary is not yet clear and remains to be elucidated. Taken together, our results indicate that oPL has no luteotropic action in sheep.

The characteristic cleavage of DNA into oligonucleosomes found in apoptosis has been shown to occur in the sheep CL at the time of luteolysis (McGuire et al. 1994) and after exogenous administration of $\mathrm{PGF}_{2 \alpha}$ during the midluteal phase (McGuire et al. 1994, Murdoch 1995). The generation of reactive oxygen species (ROS) within the CL has been suggested to be involved in the mechanism of $\mathrm{PGF}_{2 \alpha}$-induced luteolysis in the rat (Riley \& Behrman 1991, Sawada \& Carlson 1991). An in vitro study demonstrated that $\mathrm{PGF}_{2 \alpha}$ induced apoptosis through the production of ROS by rat luteal cells (Tanaka et al. 2000). Recently, we showed that the activities of key antioxidant enzymes in the sheep CL are subject to major changes during the first trimester of pregnancy, suggesting that the CL of early pregnancy may be rescued from luteolysis through increasing activities of antioxidant enzymes and inhibition of apoptosis (Al-Gubory et al. 2004). In addition, in vitro (Sugino et al. 1998) and in vivo (Takiguchi et al. 2000) experiments demonstrated that rodent PL have stimulatory effects on SODs expression in the rat CL, suggesting that PL may play important roles in the maintenance of luteal function and structure by increasing the antioxidant capacities of the CL. Experiment 2 of the present study was designed to examine whether oPL could protect the CL from apoptosis by increasing the activity of key antioxidant enzymes. Treatments of ewes with roPL at a dose of $80 \mu \mathrm{g} / \mathrm{kg}$ live weight per day for 3 days, which began before the initiation of luteolysis, had no effect on the activity of the five main antioxidant enzymes, $\mathrm{Cu}$, $\mathrm{Zn}-\mathrm{SOD}, \mathrm{Mn}-\mathrm{SOD}, \mathrm{GPX}, \mathrm{GSR}$ and GST, and failed to prevent or reduce apoptosis. These results failed to support the hypothesis that oPL may play a role in the maintenance of sheep CL function either by inhibiting apoptosis or by increasing antioxidant status of luteal cells.

Two populations of steroidogenic cells are present within the sheep CL of the estrous cycle and pregnancy and are referred to as small and large luteal cells (O'Shea et al. 1979). Recent in vitro studies show that addition of roPL at a dose of $100 \mathrm{ng} / \mathrm{ml}$ to the culture medium increases basal progesterone secretion of ovine luteal cells isolated from CL of days 45 and 70 of pregnancy (Gregoraszczuk et al. 2000). However, addition of oPL at doses of $4 \cdot 2$ or $140 \mathrm{ng} / \mathrm{ml}$ had no effect on progesterone secretion from either small or large ovine luteal cells obtained from fully developed CL of the estrous cycle
(Rodgers et al. 1983). In the present study, the direct luteotropic effect of roPL was examined by using luteal explants from both cyclic and pregnant ewes. We used luteal explants instead of whole-cell preparations because the integrity of the luteal tissue ensures the cell-to-cell communication between different types of luteal steroidogenic cells (Rodgers 1990). We also used oLH as a positive control because it is a key endocrine regulator of CL maintenance during early pregnancy in sheep (Denamur 1968, Kaltenbach et al. 1968). Since maintenance of pregnancy in sheep (duration $\cong 150$ days) depends on progesterone secretion from the $\mathrm{CL}$ at least until day 60 (Al-Gubory et al. 1999), we used CL of day-60 pregnancy in our study. We showed that roPL added to culture media at doses of 10,100 or $1000 \mathrm{ng} / \mathrm{ml}$ had no significant effect on progesterone secretion during 24-h incubation of luteal explants obtained from CL of day 10 of the estrous cycle (experiment 3) or CL of day-60 pregnancy (experiment 4). In contrast, the secretion of progesterone by luteal explants obtained from both cyclic (experiment 3) and pregnant (experiment 4) ewes was significantly increased by the application of 100 and $1000 \mathrm{ng} \mathrm{oLH} / \mathrm{ml}$. The present in vitro experiment using ovine CL of day-60 pregnancy clearly did not support the possibility of a direct luteotropic role of oPL during early pregnancy in sheep raised by Gregoraszczuk et al. (2000).

In conclusion, these in vivo and in vitro studies failed to demonstrate luteotropic or luteoprotective actions of oPL in sheep.

\section{Acknowledgements}

We thank Ms C Hue-Beauvais and M C Poirier for assistance with photomicrograph preparation; the animalcare staff of Brouëssy and Jouy-en-Josas for excellent service; Dr A Gertler (University of Jerusalem) for his generous supply of roPL; and Dr J Djiane (INRA, Jouy-en-Josas) and Dr P A Fowler (Department of Obstetrics and Gynaecology, University of Aberdeen) for critical evaluation and comments. The authors declare that there is no conflict of interest that would prejudice the impartiality of this scientific work.

\section{References}

Akif Cam M \& Kuran M 2004 Effects of a single injection of hCG or GnRH agonist on day 12 post mating on fetal growth and reproductive performance of sheep. Animal Reproduction Science 80 81-90.

Al-Gubory KH, Solari A \& Mirman B 1999 Effects of luteectomy on the maintenance of pregnancy, circulating progesterone concentrations and lambing performance in sheep. Reproduction Fertility and Development 11 317-322.

Al-Gubory KH, Bolifraud P, Germain G, Nicole A \& Ceballos-Picot I 2004 Antioxidant enzymatic defence systems in sheep corpus luteum throughout pregnancy. Reproduction 128 767-774. 
Al-Gubory KH, Ceballos-Picot I, Nicole A, Bolifraud P, Germain G, Michaud M, Mayeur C \& Blachier F 2005 Changes in activities of superoxide dismutase, nitric oxide synthase, glutathione-dependent enzymes and the incidence of apoptosis in sheep corpus luteum during the estrous cycle. Biochimica et Biophysica Acta 1725 348-357.

Ashworth CJ, Sales DI \& Wilmut I 1989 Evidence of an association between the survival of embryo and the periovulatory plasma progesterone concentration in the ewes. Journal of Reproduction and Fertility 87 23-32.

Ayalon N 1978 A review of embryonic mortality in cattle. Journal of Reproduction and Fertility 54 483-493.

Baird DT, Land RB, Scaramuzzi RJ \& Wheeler AG 1976 Endocrine changes associated with luteal regression in the ewe: the secretion of ovarian oestradiol, progesterone and androstenedione and uterine prostaglandin $\mathrm{F}_{2 \alpha}$ throughout the oestrous cycle. Journal of Endocrinology $69275-286$.

Beck NFG, Khan TH \& Khalid M 1999 The effects of hCG treatment on day 12 post mating on conceptus growth and fertility in ewes and ewe lambs. Journal of Reproduction and Fertility. Abstract Series 2385.

Bolander FF \& Fellows RE 1976 Purification and characterization of bovine placental lactogen. Biochemical Journal 159 775-782.

Buttle HL, Forsyth IA \& Knaggs GS 1972 Plasma prolactin measured by radioimmunoassay and bioassay in pregnant and lactating goats and the occurrence of a placental lactogen. Journal of Endocrinology 53 483-491.

Carnegie JA, Chan JSD, Robertson HA, Friesen HG \& McCully ME 1977 Placental lactogen in the preattachment sheep embryo. Journal of Animal Science 45 (Suppl 1) Abstract 359.

Ceballos-Picot I, Nicole A, Clément M, Bourre JM \& Sinet PM 1992 Age-related changes in antioxidant enzymes and lipid peroxidation in brains of control and transgenic mice overexpressing copper-zinc superoxide dismutase. Mutation Research 275 281-293.

Chan JSD, Robertson HA \& Friesen HG 1978a Maternal and fetal concentrations of oPL measured by radioimmunoassay. Endocrinology 102 1606-1613.

Chan JSD, Robertson HA \& Friesen HG $1978 b$ Distribution of binding sites for ovine placental lactogen in the sheep. Endocrinology 102 632-640.

Chemineau P, Baril G, Leboeuf B, Maurel MC, Roy F, Pellicer-Rubio M, Malpaux B \& Cognie Y 1999 Implications of recent advances in reproductive physiology for reproductive management of goats. Journal of Reproduction and Fertility 54 (Suppl) 129-142.

Davies MCG \& Beck NFG 1992 Plasma hormone profiles and fertility in ewe lambs given progestagen supplementation after mating. Theriogenology 38 513-526.

Denamur R 1968 Formation and maintenance of corpora lutea in domestic animals. Journal of Animal Science 27 (Suppl 1) 163-180.

Denamur R, Martinet J \& Short RV 1973 Pituitary control of the corpora lutea. Journal of Reproduction and Fertility 32 207-220.

Galosy SS \& Talamantes F 1995 Luteotropic actions of placental lactogens at midpregnancy in the mouse. Endocrinology 136 3993-4003.

Garrett JE, Geisert RD, Zavy MT \& Morgan GL 1988 Evidence for maternal regulation of early conceptus growth and development in beef cattle. Journal of Reproduction and Fertility 84 427-446.

Gavrieli Y, Sherman Y \& Ben-Sasson SA 1992 Identification of programmed cell death in situ via specific labeling of nuclear DNA fragmentation. Journal of Cell Biology 119 493-501.

Gertler A \& Djiane J 2002 Mechanism of ruminant placental lactogen action: molecular and in vivo studies. Molecular Genetics and Metabolism 75 189-201.

Gibori G 1993 The corpus luteum of pregnancy. In The Ovary, pp 261-317. Eds EY Adashi \& PCK Leung. New York, NY, USA: Raven Press.
Gibori G, Khan I, Warshaw ML, McLean MP, Puryear TK, Nelson S, Durkee TJ, Azhar S, Steinschneider A \& Rao MC 1988 Placental-derived regulators and the complex control of luteal cell function. Recent Progress in Hormone Research 44 377-429.

Glaser LA, Kelly PA \& Gibori G 1984 Differential action and secretion of rat placental lactogens. Endocrinology 115 969-976.

Greenwood FC, Hunter WM \& Glover JS 1963 The preparation of I-131-labelled human growth hormone of high specific radioactivity. Biochemical Journal 85 114-123.

Gregoraszczuk EL, Zieba D, Wierzchos E, Murawski M \& Gertler A 2000 Placental lactogen as a regulator of luteal cells function during pregnancy in sheep. Theriogenology 53 877-885.

Herman A, Bignon C, Daniel N, Grosclaude J, Gertler A \& Djiane J 2000 Functional heterodimerization of prolactin and growth hormone receptors by ovine placental lactogen. Journal of Biological Chemistry 275 6295-6301.

Kaltenbach CC, Graber JW, Niswender GD \& Nalbandov AV 1968 Luteotrophic properties of some pituitary hormones in non-pregnant or pregnant hypophysectomized ewes. Journal of Endocrinology 82 818-824.

Kann G, Delobelle A, Belair L, Gertler A \& Djiane J 1999 Demonstration of in vivo mammogenic and lactogenic effects of recombinant ovine placental lactogen and mammogenic effect of recombinant ovine $\mathrm{GH}$ in ewes during artificial induction of lactation. Journal of Endocrinology 160 365-377.

Kelly PA, Robertson HA \& Friesen HG 1974 Temporal pattern of placental lactogen and progesterone secretion in sheep. Nature 248 435-437.

Khan I, Glasser LA \& Gibori G 1987 Reactivation of regressing corpora lutea by estradiol in the pregnant rat: dependence on placental lactogen. Biology of Reproduction 37 1083-1088.

Khan TH, Hastie PM, Beck NFG \& Khalid 2003 hCG treatment on day of mating improves embryo viability and fertility in ewe lambs. Animal Reproduction Science 76 81-89.

Kleemann DO, Walker SK \& Seamark RF 1994 Enhanced fetal growth in sheep administered progesterone during the first three days of pregnancy. Journal of Reproduction and Fertility 102 411-417.

Lowry OH, Rosebrough NJ, Farr AL \& Randall RF 1951 Protein measurement with folin phenol reagent. Journal of Biological Chemistry 193 265-275.

Martal J \& Djiane J 1975 The production of chorionic somatomammotrophin in sheep placenta. Biochemical and Biophysical Research Communications 65 770-778.

Martal J \& Djiane J 1977 The production of chorionic somatomammotrophin in sheep. Journal of Reproduction and Fertility $49285-289$.

McCracken JA, Carlson JC, Glew ME, Goding JR, Baird DT, Green K \& Samuelsson B 1972 Prostaglandin $F_{2 \alpha}$ identified as a luteolytic hormone in sheep. Nature New Biology 238 129-134.

McGuire WJ, Juengel JL \& Niswender GD 1994 Protein kinase C second messenger system mediates the antisteroidogenic effects of prostaglandin $\mathrm{F}_{2 \alpha}$ in the ovine corpus luteum in vivo. Biology of Reproduction $\mathbf{5 1} 800-806$.

Menegatos J, Chadio S, Kalogiannis T, Kouskoura S \& Kouimtzis S 2003 Endocrine events during the oestrous period and the subsequent estrous cycle in ewes after estrus synchronization. Theriogenology 59 1533-1543.

Murdoch WJ 1995 Temporal relationships between stress protein induction, progesterone withdrawal, and apoptosis in corpora lutea of ewes treated with prostaglandin $\mathrm{F}_{2 \alpha}$. Journal of Animal Science 73 1789-1792.

Nephew KP, Cardenas H, McClure KE, Ott TL, Bazer FW \& Pope WF 1994 Effects of administration of human gonadotropin or progesterone before maternal recognition of pregnancy on blastocyst development and pregnancy in sheep. Journal of Animal Science 72 453-458.

Niswender GD 2002 Molecular control of luteal secretion of progesterone. Reproduction 123 333-339. 
O'Shea JD, Cran DG \& Haw MF 1979 The small luteal cell of the sheep. Journal of Anatomy 128 239-251.

Rajamahendran R \& Sianangama PC 1992 Effect of human chorionic gonadotropin on dominant follicles in cows: formation of accessory corpora lutea, progesterone production and pregnancy rates. Journal of Reproduction and Fertility 95 577-584.

Riley JC \& Behrman HR 1991 In vivo generation of hydrogen peroxide in the rat corpus luteum during luteolysis. Endocrinology 128 1749-1753

Robinson NA, Leslie KE \& Walton JS 1989 Effect of treatment with progesterone on pregnancy rate and plasma concentrations of progesterone in Holstein cows. Journal of Dairy Science 72 202-207.

Rodgers RJ 1990 Cell-cell communication in corpora lutea. Reproduction, Fertility, and Development 2 281-289.

Rodgers RJ, O’Shea JD \& Findlay JK 1983 Progesterone production in vitro by small and large ovine luteal cells. Journal of Reproduction and Fertility 69 113-124.

Roy F, Maurel MC, Combes B, Vaiman D, Cribiu EP, Lantier L, Pobel T, Delétang F, Combarnous Y \& Guillou F 1999a The negative effect of repeated equine chorionic gonadotropin treatment on subsequent fertility in alpine goats is due to a humoral immune response involving the major histocompatibility complex. Biology of Reproduction $\mathbf{6 0} 805-813$.

Roy F, Combes B, Vaiman D, Cribiu EP, Pobel T, Delétang F, Combarnous Y, Guillou F \& Maurel MC 1999b Humoral immune response to equine chorionic gonadotropin in ewes: association with major histocompatibility complex and interference with subsequent fertility. Biology of Reproduction 61 209-218.

Sakal E, Bignon C, Grosclaude J, Kantor A, Shapira R, Leibovitch H, Helman D, Nespoulous C, Shamay A, Rowlinson SW et al. 1997 Large-scale preparation and characterization of recombinant ovine placental lactogen. Journal of Endocrinology 152 317-327.

Santos JEP, Thatcher WW, Pool L \& Overton MW 2001 Effect of human chorionic gonadotropin on luteal function and reproductive performance of high-producing lactating Holstein dairy cows. Journal of Animal Science 79 2881-2894.

Sawada M \& Carlson JC 1991 Rapid plasma membrane changes in superoxide radical formation, fluidity, and phospholipase $\mathrm{A}_{2}$ activity in the corpus luteum of rat during induction of luteolysis. Endocrinology 128 2992-2998.

Schanbacher BD 1979 Radioimmunoassay of ovine and bovine serum progesterone without extraction and chromatography. Endocrine Research Communications 6 263-277.
Schmitt EJP, Diaz T, Barros CM, de la Sota RL, Drost M, Fredriksson EW, Staples CR, Thorner R \& Thatcher WW 1996 Differential response of the luteal phase and fertility in cattle following ovulation of the first-wave follicle with human chorionic gonadotropin or an agonist of gonadotropin-releasing hormone. Journal of Animal Science 74 1084-1091.

Schramm W, Friesen HG, Robertson HA \& McCracken JA 1984 Effect of exogenous placental lactogen on luteolysis by prostaglandin F-2 $\alpha$ in sheep. Journal of Reproduction and Fertility 70 557-565.

Shelton K, De Abreu MFG, Hunter MG, Parkinson TJ \& Lamming GE 1990 Luteal inadequacy during the early luteal phase of subfertile cows. Journal of Reproduction and Fertility 90 1-10.

Stacy BD, Gemmell RT \& Thorburn GD 1976 Morphology of the corpus luteum in the sheep during regression induced by prostaglandin $\mathrm{F}_{2 \alpha}$. Biology of Reproduction 17 280-291.

Sugino N, Hirosawa-Takamori M, Zhong L, Telleria CM, Shiota K \& Gibori G 1998 Hormonal regulation of copper-zinc superoxide dismutase and manganese superoxide dismutase messenger ribonucleic acid in the rat corpus luteum: induction by prolactin and placental lactogen. Biology of Reproduction 59 599-605.

Takiguchi S, Sugino N, Kashida S, Yamagata Y, Nakamura Y \& Kato H 2000 Rescue of the corpus luteum and an increase in luteal superoxide expression induced by placenta luteotropins in the rat: action of testosterone without conversion to estrogen. Biology of Reproduction 62 398-403.

Tanaka M, Miyazaki T, Tanigaki S, Kasai K, Minegishi K, Miyakoshi K, Ishimoto H \& Yoshimura Y 2000 Participation of reactive oxygen species in PGF2 alpha-induced apoptosis in rat luteal cells. Journal of Reproduction and Fertility 120 239-245.

Thatcher WW, Staples CR, Danet-Desnoyers G, Oldick B \& Schmitt E-P 1994 Embryo health and mortality in sheep and cattle. Journal of Animal Science 72 (Suppl 3) 16-30.

Waters MJ, Oddy VH, McCloghry CE, Gluckman PD, Duplock PC \& Brinsmead MW 1985 An examination of the proposed roles of placental lactogen in the ewe by means of antibody neutralization. Journal of Endocrinology 106 377-386.

Wheeler CR, Salzman JA, Elsayed NM, Omaye ST \& Korte DW Jr 1990 Automated assays of superoxide dismutase, catalase, glutathione peroxidase, and glutathione reductase activity. Analytical Biochemistry 184 193-199.

Received 16 December 2005 Accepted 19 December 2005 